\section{Midland Section of the Institute of Physics}

THE second Local Section of the Institute of Physics to be formed in Great Britain was inaugurated at a. meeting held at the University of Birmingham on Friday, November 15. Prof. S. W. J. Smith was elected chairman, and Dr. J. H. Mitchell, of the British Thomson-Houston Research Laboratory, local honorary secretary, from whom further details may be obtained. The inaugural lecture was given by Dr. J. D. Cockcroft, of the Cavendish Laboratory, Cambridge, who took as his subject "Recent Work on Nuclear Transmutations". It is proposed to hold the meetings of this new Section in Rugby and Leicester and possibly other towns in the Midlands during the session.

\section{Forthcoming Eclipse of the Sun in U.S.S.R.}

The Academy of Sciences of the U.S.S.R. has issued a report ("Bulletin de la Commission pour les recherches du Soleil", 13) by Profs. Gerasimovič and Šerbakova, dealing with the circumstances of the forthcoming total solar eclipse. The eclipse will take place on June 19, 1936, and the line of totality crosses the U.S.S.R. from the North Caucasus, over the Volga steppes, and over Siberia to the far eastern provinces. The track passes over both Omsk and Tomsk, which are of course large cities which will offer facilities to observers. In the present report, an account is given of the meteorological data which have been specially collected since 1933 at various stations along the track of totality, in order that prospective observers of the eclipse may have the best choice of stations likely to enjoy clear weather on the day of the eclipse.

\section{Astronomical Spectrography}

Messr. Hilger's new catalogue of astronomical spectrographs and spectroscopes shows that this firm is maintaining its reputation for keeping abreast with the latest developments. Among the major instruments which it has recently constructed are the 3 -prism spectrograph for the 36 -in. reflector at the Royal Observatory, Edinburgh, and the spectrograph for the 74-in. reflector at Toronto. The first of these follows the general design of that at the Dominion Observatory, Vancouver, but contains many improvements; the second is designed for radial velocity work with a single prism and has a special mounting designed to reduce flexure to a minimum. The firm has also made a slitless spectrograph for the Royal Observatory, Greenwich, following a design of Mr. C. R. Davidson. Messrs. Hilger now offer as standard productions a spectroscope for observing solar prominences designed by Mr. J. Evershed, and a direct-vision constant deviation monochromator recently designed by Prof. H. H. Plaskett.

\section{Announcements}

Prof. F. G. Donnan, professor of chemistry in the University of London and director of the Chemical Laboratories, University College, London, has been elected a foreign member of the Division for Chemistry of the Royal Physiographical Society of Lund (Sweden).

Dr. C. E. K. MEes, vice-president in charge of research and development in the Eastman Kodak Co., Rochester, U.S.A., will deliver six Christmas Lectures "adapted to a juvenile auditory" at the Royal Institution on Saturdays, Tuesdays and Thursdays, commencing on December 28. The subject of Dr. Mees's lectures will be "Photography". Further information can be obtained from the Secretary, Royal Institution, 21 Albemarle Street, London, W.1.

A DIscussion on "Ice Ages", arranged by the Royal Meteorological Society and the Royal Astronomical Society, will be held on January 31 at 4.30 in the rooms of the Royal Astronomical Society, Burlington House, London, W.1. The discussion will be opened by Sir George Simpson.

THE Empire's Airway Exhibition at the Science Museum, South Kensington, organised by Imperial Airways, Ltd., will be opened by the Secretary of State for Air in the lecture theatre of the Museum at 11 a.m. on Thursday, December 5. The chair will be taken by Sir Eric Geddes.

THE Exhibition of Kinematography at the Royal Photographic Society, 35 Russell Square, W.C.1, is to remain open to the public until Saturday, November 30. The exhibition is mainly devoted to 'stills' from films. Some very fine photography is shown. A certain amount of apparatus is shown, notably that for recording and reproducing sound with $16 \mathrm{~mm}$. picture film.

THE National Trust has accepted from the Viscountess Rhondda and the Dowager Viscountess Rhondda some 2,130 acres of the Sugar Loaf, just north of Abergavenny. This magnificent hill, which is well known in South Wales and Monmouth, is at the south end of the Black Mountains and rises to a height of nearly 2,000 feet.

Applications are invited for the following appointments, on or before the dates mentioned:

A technical officer, an assistant (grade II) and assistants (grade III) for work in wireless equipment at the Royal Aircraft Establishment, South Farn. borough, Hants - The Chief Superintendent (Nov. 29).

A University lecturer and a University demonstrator in biochemistry in the University of Cambridge-Sir F. G. Hopkins, Sir William Dunn Institute of Biochemistry, Cambridge (Dec. 7).

A research assistant to the Animal Diseases Research Association-The Secretary, Moredun Institute, Gilmerton, Midlothian (Dec. 20).

A Jacksonian professor of natural philosophy in the University of Cambridge-The Vice-Chancellor (Dec. 31).

A head of the silk section of the British Cotton Industry Research Association-Dr. R. H. Pickard, Shirley Institute, Didsbury, Manchester. 